\title{
The Effect of Services Marketing Mix Elements on Customer-Based Brand Equity: An Empirical Study on Mobile Telecom Service Recipients in Jordan
}

\author{
Hani Al-Dmour ${ }^{1}$, Zu'bi M. F. Al-Zu'bi ${ }^{1} \&$ Dana Kakeesh $^{1}$ \\ ${ }^{1}$ Business School, University of Jordan, Amman, Jordan \\ Correspondence: Zu'bi M. F. Al-Zu'bi, University of Jordan, P.O. Box 13413, Amman, 11942, Jordan. Tel: \\ 962-79-562-939. E-mail: z.alzubi@ju.edu.jo
}

Received: December 18, 2012

Accepted: January 11, 2013

Online Published: May 16, 2013

doi:10.5539/ijbm.v8n11p13

URL: http://dx.doi.org/10.5539/ijbm.v8n11p13

\begin{abstract}
The purpose of this research is to study the effect of services marketing mix elements on customer-based brand equity through empirical study of mobile telecommunication service recipients. It also aims to determine the influence of such elements on customer-based brand equity and to reveal which is the most influential.

We employed a questionnaire-based survey consisting of 56 questions and distributed to 1,930 respondents in the three largest governorates in Jordan: Amman, Irbid, and Al-Zarqa. In total, 1,492 questionnaires were returned, corresponding to a response rate of $77 \%$. In order to analyze the data obtained from questionnaires, quantitative methods were employed, and reveal that there is a significant effect of services marketing mix elements upon customer-based brand equity.

The study suggests that customer-based brand equity is a valuable asset for any services sector, especially for marketing managers to assess the results of their efforts by getting feedback from customers to diagnose any problem that can appear in the provided service. In addition, customer-based brand equity provides a clear approach which can be employed by managers for the design and creation of branding strategy. This should enable managers to minimise problems that could arise from limited resources.
\end{abstract}

Keywords: service marketing, customer-based brand equity, Jordan

\section{Introduction}

Service in Jordan is considered to be most prominent amongst economic sectors, comprising $67 \%$ of the GDP. The large contribution of the service sector to GDP compared with the small contribution of the industrial and agricultural sectors results in a service-oriented economy (Statistical Yearbook, 2009). Recent years have seen rapid changes in the service sector and the increased competition between firms, which has increased the importance of services brand management. All these conditions have increased pressure upon the most dynamic member on the service sector: the mobile telecommunication sector. Managers in this sector find themselves faced with increasing demands from customers, and face new challenges to achieve what they want and provide clients with superior services in light of the existence of higher competition in the marketplace.

This issue is essential in the design and development of the company's service offerings because the ultimate goal of any company is to have valuable brand equity. This means that the manager must give more attention and care to the company-marketing program by developing effective services marketing mix (SMM) elements that can increase brand equity over competitors. Thus, this research investigates the influence of services marketing mix on customer-based brand equity, and serves as an empirical study of mobile services recipients. The literature review reveals a large amount of research related to service marketing (Langeard et al., 1981; Zeithaml et al., 1985; Onkvisit and Shaw, 1989; Bitner, 1990, 1992; Gronroos, 1994). Many of the studies criticise the traditional concept of marketing mix that was introduced for the first time by Borden in 1948 (Shostack 1977; 1976; Kent, 1986). Booms and Bitner (1981) introduced the " 3 P's" of service marketing mix-people, physical evidence, and process-to figure out services problem by having more comprehensive model specified for service product.

On the other hand, the definition and quantification of brand equity is of considerable interest to many researchers (Aaker, 1991;1996; Keller, 1993; Lasser, 1995) because of the necessity in today's marketplace to develop and 
utilize product branding to ensure that companies can enjoy competitive advantage (Pitt and McCarthy, 2008). It is now appreciated that brands are intangible assets, which has been reflected by an increased emphasis in the literature on the ways in which brand equity can be developed, maintained and measured (Keller, 2008; 2003). In general, brand equity is viewed from one of three perspectives, distinguished by being customer-based, company-based or financially-based (Aaker, 1996; Keller and Lehmman, 2003b). This research uses the customer-based brand equity (CBBE) approach. At the same time, many academics were attempting to develop various models to measure the brand equity (Aaker 1993; 1996; and Lasser, 1995) depending mainly on Keller (1993) CBBE dimensions.

\subsection{Problem Statement}

Since the Jordanian services market is rapidly changing, and service companies experiencing increased competition, the management of service brands has gained greater significance. It is not straightforward to assess customer-based brand equity. As a largely intangible and complex concept, it is difficult for a customer to contrast the offerings of various service companies on the market. Consequently, this research aims to investigate out the effect of services marketing mix on customer-based brand equity: an empirical study on mobile telecom service recipients, and to answer the following research questions:

1) How much do marketing mix elements of mobile telecommunication service effect on the costumer-based brand equity?

2) Within SMM, which elements have greatest influence on CBBE?

\subsection{Significance}

Despite the considerable progress of previous research in explaining the link between SMM and CBBE this study adds further insight to understand of this link. In addition, this research has the following important aspects:

1) The mobile service providers (MSP) are amongst the fastest growing companies in the service sector in Jordan. This rapid growth has been accompanied by other dramatic changes that have begun to exert significant pressures on MSPs to raise the value of their brands and to provide better services than what the other competitors in the market place do.

2) The scarcity of Jordanian studies on the CBBE gave the advantage of this research in helping the Jordanian managers to start thinking about their mobile telecom service recipients and organizing their marketing efforts in order to raise their CBBE.

3) It is an empirical study applied on the main MSPs in Jordan (Zain, Orange, and Umniah) which means that the results of this study will be very important to each company in order to increase or to maintain their competitive advantages in the market place.

\subsection{Study Conceptual Framework}

Rathmell (1966) defined services as acts, deeds, performances, or efforts. Zeithaml, et al., (1985) described services similarly to Rathmell's definition as deeds, processes, and performances delivered from one entity or individual to another entity or individual. Service is mainly intangible product transfer the benefit from one party to another without transferring the ownership of this kind of product (Kotler et al., 2005). Lovelock and Writz (2007, p.15) stated services as "an economic activities offered by one party to another, most commonly employing time-based performances to bring about desired results in recipients themselves or in objects or other assets for which purchasers have responsibility." Services are often described in contrast to goods. A good is a tangible item that can be produced, sold, and then consumed later, while a service is intangible and perishable. It is sold, produced, and then consumed. This study builds on Rathmell's (1966) definition.

Keller (1993) defines CBBE as "the differential effect of brand knowledge on consumer response to the marketing of the brand." Keller includes three main concepts in his definition. The first one is the "differential effect" and this can be determined by comparing the customer's response toward the marketing of a brand with the response to the marketing of other brand from the same category. The second one is "brand knowledge" and comprises two principal components: brand awareness-the extent to which customers are aware about a brand, and brand image, which reflects the association customers hold in their mind regarding a brand. The final concept is "consumer response" this can be described as the consumer perceptions, preferences, and behavior toward the marketing activities. A brand has positive CBBE when a customer's reaction is considered to be positive toward the brand and vice-versa.

Aaker (1991; 1996) incorporates both perceptual and the behavioral dimensions. He lists ten sets of measures divided into five categories. The first four categories - perception of quality, loyalty to a brand, awareness of a 
brand, and brand association - are concerned with the customer. The last one, other propriety assets, is related to the market wherein the firm is operating. Aaker contents that brand loyalty reflects the level of commitment exhibited by a consumer for a particular brand. Brand awareness is related to the potential for a customer to identify a brand among competitors' products in the marketplace. Brand association describes any memory or perception that a customer may have in connection to the brand. Proprietary brand assets refer to special issues like the patents and trademarks. The stronger these dimensions are, the higher the resulting brand equity.

In contrast to Aaker's (1991) focus on the five brand equity dimensions discussed above, Keller's (1993) approach is to either indirectly or directly measure CBBE from the point of view of just two constructs: brand image and brand awareness. The indirect approach involves identification of possible sources of CBBE such as channels of distribution, the efficacy of communicating about the marketing, and the success of strategies to extend the brand by, for example, measuring brand awareness and exploring the mechanisms of brand associations. The direct approach, on the other hand, primarily involves studies of how consumers respond to various aspects of the marketing strategy of the company (Keller, 2003).

Lasser et al. (1995), modify the previous scales used by practitioners. Their main modifications concentrate on four main aspects. First they replace the quality dimension with performance, and then they use the social dimension instead of the image dimension. Third, they try to clearly distinguish between the feeling commitment and the action commitment. Finally, they constitute a specific definition for both value and trustworthiness as a part from brand equity. Brand knowledge can be considered to comprise primarily of brand awareness and brand image. This construct has been used in the CBBE framework proposed by Keller (1993).

Yoo et al. (2000) adopt three of the dimensions from the Aaker (1991) model: brand loyalty, brand association and perceived quality. The authors also extend the model by adding antecedents of brand equity, which they identify as price, price deals, distribution intensity, store image and advertising expenditure. Their study reveals that these dimensions have a significant effect on brand equity. Prasad and Dev (2000) and Low and Lamb Jr (2000) both adopt four of Aaker's (1991) components: brand awareness, brand association, perceived quality, and brand loyalty.

For the purpose of this study, four dimensions explored, comprised of three perceptual dimensions-perceived quality, brand image and brand awareness, brand image, and one behavioural dimension-brand loyalty. Brand image is used interchangeably with brand association. According to Keller (2003), brand image relates to the associations related to the brand that exist within the minds of customers, and comprises all expectations and knowledge relating to a particular product or service.

Empirical studies which focused on SMM were identified using the scholarly Internet search engine scholar.google.com, in addition to various online databases encompassing leading journals in a range of fields including marketing service and brand equity. A number of studies related to SMM can be found in various marketing journals and magazines. However, many of them are conceptual or non-empirical studies using either a qualitative or quantitative approach. For example, a study by Kayaman and Arsalai (2007) aimed to identify the relationship among four dimensions of brand equity: brand image, brand awareness, brand loyalty and perceived quality. In this work they propose a conceptual framework to describe hotel brand equity. This study examines five-star hotels in northern Cyprus. The model was developed by considering perceived quality as independent variable and the other three brand equity dimensions as a dependent variables. The conclusions of the study are that that awareness has only minimal effect on brand equity, but at the same time brand image, brand loyalty and perceived quality are important factors in building brand equity in the hotel sector. Finally, this study recommends that executive managers pay more attention to these variables for their significant importance in designing and providing services.

Akroush and Al-Dmour (2006) study seventeen commercial banks to investigate the relationship between branding benefits and brand-building factors within commercial banks operating in Jordan. This study adopts a model that consists of corporate culture, internal marketing, service delivery process, atmospherics, distinctive banking product, marketing communication, and cross functional team as independent variables, while the building brand benefits which encompass overall benefits, financial benefits, and non-financial benefits as dependent variables. The study found a strong and positive correlation between the brand building factors and the overall brand benefits; financial and non-financial. The important finding is that service delivery process, atmosphere, and marketing communication and non-financial benefits (i.e. brand image) are related. Akroush and Al-Dmour recommend that the managers focus on providing distinctive banking products, in order to build customer-oriented corporate culture, and to pay more attention to the employees in front offices. They also suggest to focus also on marketing communications, atmospherics, and service delivery activities in order to enhance 
building a desirable image in the marketplace. In another study, Akroush, et al. (2006) aimed to study how SMM elements affect customer satisfaction relating to comprehensive motor insurance. The study identifies significant and positive relationship between the summated SMM components and customer satisfaction. This paper also reports a significant positive correlation between the new 3P marketing mix (processes, people and physical evidence) on the satisfaction enjoyed by customers. They also mentioned that the 3P's effect on customer satisfaction is stronger than the effect of the traditional marketing mix components.

Rajh \& Dosen (2009) explore how various marketing mix elements affect service brand equity. This work has greatest value in its reports of how different elements have different effects on service brand e quity, and by showing how essential it is to develop approaching the development of service brand in a strategic manner. In addition, the findings draw conclusions relating to the necessity for concerted efforts regarding employees, advertising, price level, interior appearance and service operation, as each of these factors positively affects service brand equity. The results indicate how important it is to build service brands strategically, with a primary long-term goal to establish service brand equity.

Faircloth et al. (2001) investigates how brand image and attitude affect brand equity. The authors perform an empirical study of a conceptual model derived from work by Aaker (1991) and Keller (1993). The results suggest the manipulation of brand equity through communication of specific signals or brand associations to consumers, which will influence attitudes and images of customers to these brands, hence affecting brand equity. The researcher also suggests a focus on specific constructs that have greatest influence on brand equity, rather than attempting to quantify total monetary performance.

Yoo et al. (2000) explore how brand equity can be created by certain marketing mix elements. The paper outlines a conceptual framework describing the relationship between various dimensions of brand equity and marketing elements. Specifically, these dimensions are brand loyalty, perceived quality, brand associations and brand awareness. The research hypotheses were tested empirically using structured equation modeling, which found that price deals and other price promotions give rise to low brand equity while increased spending on advertising, higher prices, greater intensity of distribution and improved store image have a significant positive relationship to high brand equity.

Cobb-Walgren et al. (1995) performed a study using a perception-based measure of brand equity from the perspective of the customer. The study uses the Aaker (1991) conceptualization as adopted by Keller (1993) brand association, brand awareness and perceived quality. Specifically, the work investigated hotel and househould cleanser used in the service sector to explore the effect of brand equity on consumer's preference and purchase intention. The results show that brand equity increases both consumer's preference and purchase intention.

\section{Methods}

\subsection{The Study's Model}

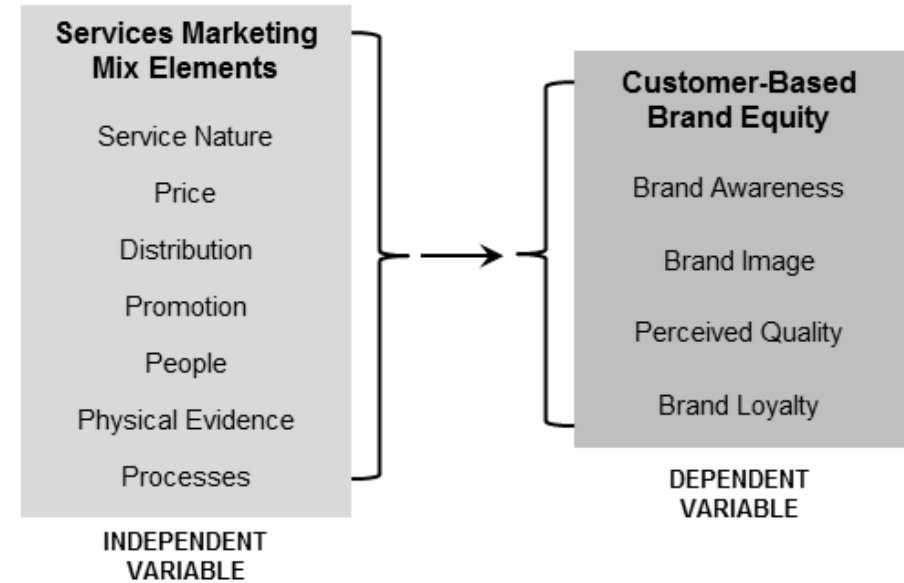

Figure 1. The model of this study

Our theoretical research model arises from our review of the literature and the aforementioned study objectives.

Figure 1 presents the research model developed for the purposes of this research. It consists one dependent 
variable-customer-based brand equity (CBBE) and one independent variable-the service marketing mix elements. This is affected by the independent variables, the service marketing mix elements. These elements were derived from previous research, where all were independently found to be related to increased levels of CBBE. However, they had not been combined and tested in the same study. The research proposes four dependent variables: brand image, brand awareness, brand locality and perceived quality).

\subsection{Operational Definitions}

Independent Variable (Services Marketing Mix) is defined as "the set of tools available to an organization to shape the nature of its offer to customers". These elements are:

1) Service elements are defined as the intangible activities and performance designed by interactive process in order to satisfy customer needs and expectations, and convince them, this process could be done by using tangible products. Table 1 shows the five items used to operationalise this construct.

2) Price elements are defined as the value of items which are needed for the acquisition of a product. Table 1 shows the four items were used to operationalise this construct.

3) Distribution/Place refers to the personnel and firms involved in the development of a product from producer to user. Table 1 shows the six items were used to operationalise this construct.

4) Promotion includes all of the tools available to the marketer to transform their message about the product strategy to the target market; moreover, this consists of communication mix. Table 1 shows the six items were used to operationalise this construct.

5) People consist of staff with the required attitude, service knowledge and relational skills to ensure that the consumers will receive the service for which they are paying. Table 1 shows the five items were used to operationalise this construct.

6) Physical Evidence is the environment in which the service is delivered and any tangible goods that facilitate the performance and communication of the service. Customers look for clues to the likely quality of a service also by inspecting the tangible evidence. Table 1 shows the four items were used to operationalise this construct.

7) Process means procedures, mechanism and flow of activities by which a service is acquired. Process decisions radically affect how a service is delivered to customers. Table 1 shows the six items were used to operationalise this construct.

\section{Dependent Variables, Customer-Based Brand Equity:}

Brand equity is the "added value" with which a given brand endows a product (Farquhar, 1989, p. 7). Aaker (1991, p. 38) defines brand equity as "a set of brand assets and liabilities linked to a brand, its name and symbol that add to or subtract from the value provided by a product or service to a firm and/or to that firm's customers." Keller (1993, p. 8) defines CBBE as the differential effect of brand knowledge on how a consumer will respond to brand marketing.

1) Brand Awareness: how well a potential buyer is able to observe and remember that a brand lies within a particular class of products (Aaker, 1991). Table 1 shows the three items used to operationalise this construct.

2) Brand Image: is a consumer's perception about the brand as reflected by the brand associations held in his or her mind (Keller, 2008). Table 1 shows the six items were used to operationalise this construct.

3) Perceived Quality: “The consumer's judgment about a product's overall excellence or superiority” (Zeithaml, 1988). Table 1 shows the four items were used to operationalise this construct.

4) Brand Loyalty: defined by Aaker (1991) as the affection felt by a customer to a particular brand. Table 1 shows the three items that were used to operationalise this construct.

5) Overall Brand Equity: table 1 shows the four items were used to operationalise this construct. 
Table 1 . The scales of measuring the study items

\begin{tabular}{l} 
No. $\quad$ Services Marketing Mix Elements \\
\hline The Services nature \\
1. My mobile service provider provides me with distinctive after sale services. \\
2. My mobile service provider cares about my opinion in the development of new services. \\
3. I deal with a mobile service provider that has a distinctive brand in the market. \\
4. My mobile service provider provides me with updates about developed service products. \\
5. My mobile service provider provides me with a variety of services
\end{tabular}

\section{The Price}

Yoo et al. (2000)

6. My mobile service provider provides me with more than one paying facility/ option.

7. My mobile service provider's prices are appropriate to me.

8. The prices are appropriate compared to the quality of services provided.

9. The prices are competitive compared to the other mobile service providers.

\section{The Distribution/Place}

10. My mobile service provider has many branches within my region of residence.

11. The number of outlets that deal with my mobile services provider are more than those of its competing brands.

12. My mobile service provider's location is appropriate for me.

13. The website essential base for dealing with my mobile service provider (paying the bills, detailed bill on your e-mail.... etc.) is satisfactory.

14. My mobile service provider website is well-organized.

15. Signs of my mobile service provider's location are available.

\section{The Promotion}

16. The advertising campaigns seem very creative, compared to campaigns for competing brands.

17. The advertisements are frequently seen through media such as TV, radio and billboards.

18. In general, I can feel that there is a credibility in the advertisements.

19. My mobile service provider gives me special offers from time to time (i.e.: free hours, sms, mms, ... etc.).

20. My mobile service provider cares about cultural activities and program sponsorship (i.e.: independent day festival, social events, sport games, ...etc.).

21. When I decide to purchase a specific service, I take into consideration the spoken word of mouth from friends and relatives.

People

22. The staff is able to provide the required services quickly.

23. Most of the time the staff is able to answer my inquiries.

24. The staff is well-trained and know how to deal with customers.

25. The staff treats me as a special and valued customer.

26. The staff is always willing and ready to deliver the service to me.

\section{Physical Evidence}

Source(s)

Akroush et al. (2006)

\author{
Yoo et al. (2000)
}

Yoo et al. (2000)

Yoo et al. (2000)

Akroush et al. (2006)

Akroush et al. (2006)

27. The staff appears in attractive uniforms.

28. Public facilities (i.e.: waiting space, queuing arrangements,...etc.) of the company are comfortable and attractive.

29. My mobile service provider uses modern and sophisticated equipments.

30. The overall atmosphere is comfortable.

\section{Processes}

31. The procedures to get the required services are easy, quick and immediate.

32. My mobile service provider delivers services as promised.

33. My mobile service provider provides services to customers free of errors.

34. My mobile service provider deals with the clients in confidentiality and privacy.

35. My mobile service provider handles seriously with my complaints.

36. My mobile service provider is committed to all of the conditions offered to clients in the purchase policy.

Brand Awareness

37. It's easy to recognize my mobile service provider's name among other competing brands.

38. I am familiar with the other mobile service providers.

39. Some characteristics of my mobile service provider come to my mind quickly. 


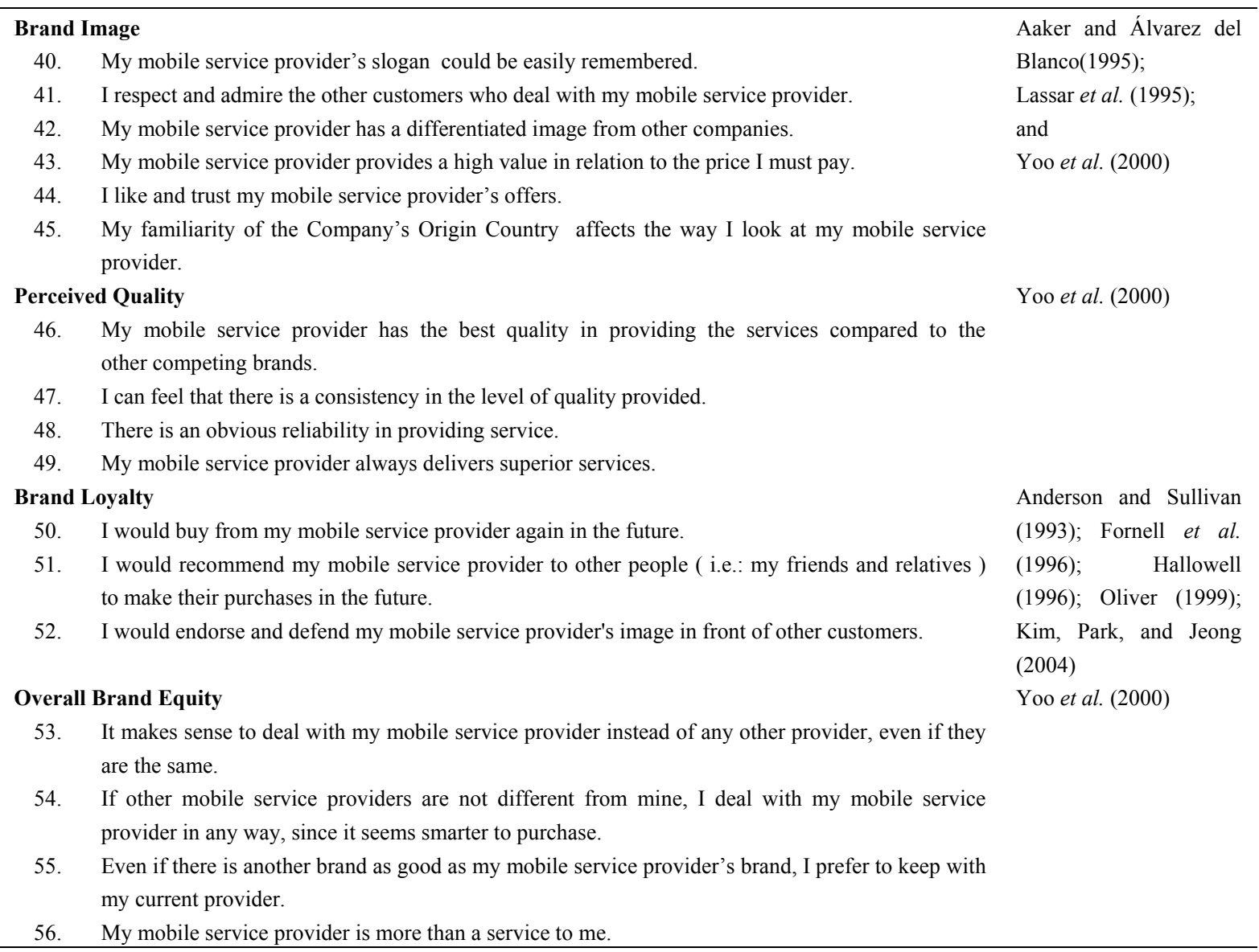

\subsection{Research Hypotheses}

Based on the previous model used, a number of hypotheses were formulated to investigate the research problem and to fulfill its goal. Three main null-hypotheses were tested in this research. The hypotheses are as listed below.

1) $\mathrm{H}_{0.1}$ : Services marketing mix elements do not have a significant effect on brand awareness.

2) $\mathrm{H}_{0.2}$ : Services marketing mix elements do not have a significant effect on brand image.

3) $\mathrm{H}_{0.3}$ : Services marketing mix elements do not have a significant effect on perceived quality.

4) $\mathrm{H}_{0.4}$ : Services marketing mix elements do not have a significant effect on brand loyalty.

\subsection{Research Design}

This section demonstrates the research design and clarifies data collection and analysis methods.

1) Research Type: This research uses two research scientific approaches, the descriptive analysis is undertaken to describe the characteristics of the variables. Empirical investigation is used to test the research hypotheses, and to explain the nature of variables relationships.

2) Population and Sampling Design: The population in this study-the group of interest-is all the mobile telecom service recipients in Jordan; this means all the clients of MSPs which are licensed as telecommunication companies at Telecommunication Regulatory Commission (TRC). The type of the sample has been decided to be a convenience sample of 2,000 respondents in order to assure an acceptable confidence in our parameters estimation. Table 2 shows how respondents vary according to the type of service provider and the city. 
Table 2. The population and the sample size

\begin{tabular}{|c|c|c|c|c|c|c|c|c|c|c|}
\hline & $\stackrel{\tilde{\omega}}{\Sigma}$ & 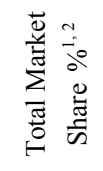 & 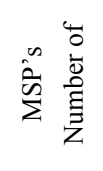 & 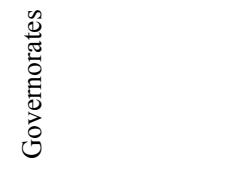 & 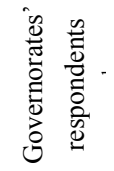 & 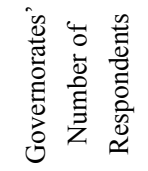 & 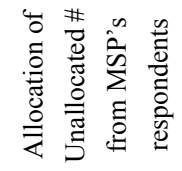 & 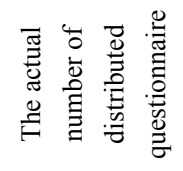 & 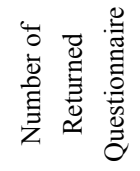 & 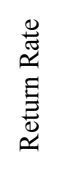 \\
\hline \multirow[t]{6}{*}{1} & Zain & 0.45 & 900 & Amman & 55.25 & 497 & $4^{3}$ & 501 & 403 & 0.80 \\
\hline & & & & Irbid & 12.40 & 112 & 1 & 113 & 78 & 0.69 \\
\hline & & & & Al-Zarka & 31.40 & 283 & 3 & 286 & 221 & 0.77 \\
\hline & & & & Unallocated \# & & 82 & - & - & & \\
\hline & & & & $\begin{array}{l}\text { from MSP' } \\
\text { respondents }\end{array}$ & & & & & & \\
\hline & & & & Total & 99.50 & 900 & 8 & 900 & 702 & 0.78 \\
\hline \multirow[t]{5}{*}{2} & Orange & 0.32 & 640 & Amman & 12.58 & 81 & 22 & 103 & 77 & 0.72 \\
\hline & & & & Irbid & 28.10 & 180 & 50 & 230 & 163 & 0.69 \\
\hline & & & & Al-Zarka & 31.50 & 202 & 56 & 258 & 205 & 0.77 \\
\hline & & & & Other & & 204 & - & - & & \\
\hline & & & & Total & 72.18 & 640 & 147 & 591 & 445 & 0.76 \\
\hline \multirow[t]{5}{*}{3} & Umniah & 0.22 & 440 & Amman & 17.92 & 79 & 5 & 84 & 77 & 0.92 \\
\hline & & & & Irbid & 35.8 & 158 & 9 & 167 & 132 & 0.79 \\
\hline & & & & Al-Zarka & 40.40 & 178 & 10 & 188 & 136 & 0.72 \\
\hline & & & & Other & & 25 & - & - & & \\
\hline & & & & Total & 94.12 & 440 & 24 & 439 & 345 & 0.79 \\
\hline \multicolumn{2}{|c|}{ Total } & 0.99 & 1,980 & - & - & 1,743 & 179 & 1,930 & $1,492^{4}$ & 0.77 \\
\hline
\end{tabular}

${ }^{1}$ Source: Ipsos state Jordan.

2 calculated as $900-(479+112+283)$.

${ }^{3}$ calculated by $8 \times 55.25 \%$.

${ }^{4} 1,949-1,553=396$ questionnaires; 273 questionnaires unreturned and 123 questionnaires invalid.

\subsection{Research Validity and Reliability}

Validity test: To ascertain the validity of the study instruments, the questionnaire was presented to a group of specialized people on the related subjects, to identify their views, and the appropriateness of all the questions to the main study objectives. They proposed some adjustments and suggested some necessary corrections to ensure improvement and validity of the instruments. The questionnaires were modified according with the notes and instructions that were taken from these people. The researchers then excluded irrelevant questions and changed unclear or difficult terminologies into simple ones.

Reliability test: Consistency-how well items fit as a set-and stability of data are both measures of reliability (Sekaran, 2003, page 307). Cronbach's alpha, in particular, is a measure of reliability, and reports mean inter-correlations between the items which measure a concept. A Cronbach's alpha of close to 1 indicates a high the internal consistency of the study tool. (Sekaran, 2003, p. 307). The Cronbach's Alpha values, and $\alpha$ was (0.941) which is considered to be good because it is greater than accepted percent $(0.60)$. These results mean that the internal consistency reliability was high and acceptable and can be considered to be highly reliable to reach the research purpose.

\section{Results}

\subsection{Hypotheses Testing}

Multiple linear regression analysis was employed in this work to investigate the research main and sub-hypotheses of this study. Multiple regressions enables researchers to examine the effect of many different factors (independent variables) on a certain outcome (dependent variable) at the same time. The general goals behind using the multiple regression method were to learn more about the relationship between several independent variables and a dependent variable, and also to investigate the functional relationships between independent and dependent variables in order to understand what might be causing the variation in the dependent variable. This section presents the main result of the research hypotheses. 


\subsubsection{Testing the first hypothesis}

$\mathrm{H}_{0.1}$ : Services marketing mix elements do not have a significant effect on brand awareness.

To test this hypothesis the multiple regression test is used, and according to the SPSS analysis, it is found that F calculated $=116.492$ is greater than $\mathrm{F}$ tabulated $=2.01$. According to the decision rule, this null-hypothesis $\mathrm{H}_{0}$ is rejected, meaning; SMM elements have a positive significant effect on brand image. R square value exhibits the capability of the independent variable in predicting the dependent variable; indicating that only $35.5 \%$ of the variation in brand image is explained by SMM elements Table 3.

Table 3. The result of multiple regression analysis for the effect of SMM elements together on brand awareness

\begin{tabular}{cccccc}
\hline F calculated & F tabulated & F Sig & R & $\mathrm{R}^{2}$ & Testing Result \\
\hline 106.845 & 2.01 & 000 & .579 & .335 & Rejected \\
\hline
\end{tabular}

Table 4 below exhibits the results of each component of SMM taken separately The result showed that the promotion element is the most influential element on brand awareness followed by processes, physical evidence, the service nature, and people in order this finding is consistent with other researchers' findings (Yoo et al., 2000; Cobb-walgren et al., 1995). Unexpectedly, the results showed that both the price and the distribution element do not have effect on brand awareness. These may indicate that creation of brand awareness is the primary goal of promotion neither the price nor the distribution, in addition to that brand awareness refers to how aware customers and potential customers are of company.

Table 4. Coefficient of the multiple regression model/ brand awareness

\begin{tabular}{|c|c|c|c|c|c|c|}
\hline & \multirow{2}{*}{ Model } & \multicolumn{2}{|c|}{ Unstandardized Coefficients } & \multirow{2}{*}{$\begin{array}{c}\text { Standardized Coefficients } \\
\text { Beta } \\
\end{array}$} & \multirow{2}{*}{$\mathrm{T}$} & \multirow{2}{*}{ Sig. } \\
\hline & & $\mathrm{B}$ & Std. Error & & & \\
\hline \multirow[t]{8}{*}{1} & (Constant) & 1.839 & .093 & & 19.842 & .000 \\
\hline & $\begin{array}{l}\text { Service } \\
\text { Nature }\end{array}$ & .069 & .023 & .077 & 3.002 & .003 \\
\hline & Price & .003 & .016 & .004 & .178 & .858 \\
\hline & Distribution & .024 & .020 & .030 & 1.184 & .237 \\
\hline & Promotion & .230 & .023 & .271 & 9.822 & .000 \\
\hline & People & .070 & .021 & .094 & 3.344 & .001 \\
\hline & $\begin{array}{l}\text { Physical } \\
\text { Evidence }\end{array}$ & .079 & .021 & .101 & 3.792 & .000 \\
\hline & Processes & .145 & .024 & .176 & 6.013 & .000 \\
\hline
\end{tabular}

${ }^{a}$ Dependent Variable: brand awareness.

\subsubsection{Testing the Second Hypothesis}

$\mathrm{H}_{0.2}$ : Services marketing mix elements do not have a significant effect on brand image.

To test this hypothesis the multiple regression test is used, and according to the SPSS analysis, it is found that F calculated=116.492 is greater than $\mathrm{F}$ tabulated=2.01. According to the decision rule, this null-hypothesis $\mathrm{H}_{0}$ is rejected, meaning; SMM elements have a positive significant effect on brand image. R square value exhibits the capability of the independent variable in predicting the dependent variable; indicating that only $35.5 \%$ of the variation in brand image is explained by SMM elements (Table 5).

Table 5. The Result of Multiple Regression Analysis for the effect of SMM elements together on brand image

\begin{tabular}{llllll}
\hline F calculated & F tabulated & F Sig & $\mathrm{R}$ & $\mathrm{R}^{2}$ & Testing Result \\
\hline 116.492 & 2.01 & 000 & .596 & .355 & Rejected \\
\hline
\end{tabular}

Table 6 exhibits the results of each component of SMM, taken separately. The result shows that all SMM elements except people element have a positive significant effect on brand image; this finding is consistent with other researchers' findings (Al-Dmour and Ayesh, 2005; Berry, 2000; Yoo, et al., 2000; Hogg, et al., 1998; 
Cobb-walgren, et al., 1995; Gronroos, 1994; Bitner, 1992; Zeithaml, et al., 1985). Processes element was the most influential element on brand image followed by the price, the service nature, the promotion, physical evidence, and distribution in order. This surprising result contradicts with previous researches results which states that people strongly affect on brand image. This result may be attributed to the narrow effect of MSP's staff on image. Therefore, company should give more attention to their staff.

Table 6. Coefficient of the multiple regression model/brand image

\begin{tabular}{|c|c|c|c|c|c|c|}
\hline \multicolumn{7}{|c|}{ Coefficients $^{\mathrm{a}}$} \\
\hline & \multirow{2}{*}{ Model } & \multicolumn{2}{|c|}{ Unstandardized Coefficients } & \multirow{2}{*}{$\begin{array}{c}\text { Standardized Coefficients } \\
\text { Beta }\end{array}$} & \multirow{2}{*}{$\mathrm{T}$} & \multirow{2}{*}{ Sig. } \\
\hline & & $\mathrm{B}$ & Std. Error & & & \\
\hline \multirow[t]{8}{*}{1} & (Constant) & -.143 & .140 & & -1.023 & .306 \\
\hline & Service Nature & .158 & .035 & .115 & 4.553 & .000 \\
\hline & Price & .236 & .024 & .236 & 9.905 & .000 \\
\hline & Distribution & .079 & .030 & .066 & 2.621 & .009 \\
\hline & Promotion & .131 & .035 & .101 & 3.719 & .000 \\
\hline & People & -.035 & .032 & -.031 & -1.098 & .272 \\
\hline & Physical Evidence & .109 & .031 & .091 & 3.482 & .001 \\
\hline & Processes & .307 & .036 & .243 & 8.409 & .000 \\
\hline
\end{tabular}

${ }^{a}$ Dependent Variable: Brand Image

\subsubsection{Testing the Third Hypothesis}

$\mathrm{H}_{0.3}$ : Services marketing mix elements do not have significant effect on perceived quality.

The multiple regression test is used to test this hypothesis, and according to the SPSS analysis, it is found that F calculated $=154.128$ is greater than $\mathrm{F}$ tabulated $=2.01$. According to the decision rule, this hypothesis $\mathrm{H}_{0}$ is rejected, meaning; SMM elements have a positive significant effect on perceived quality. $\mathrm{R}$ square value exhibits the capability of the independent variable in predicting the dependent variable; indicating that $42.1 \%$ of the variation in perceived quality is explained by SMM elements Table 7.

Table 7. The Result of multiple regression analysis for the effect of smm elements together on perceived quality

\begin{tabular}{cccccc}
\hline F calculated & F tabulated & F Sig & R & $\mathrm{R}^{2}$ & Testing Result \\
\hline 154.128 & 2.01 & 000 & .649 & .421 & Rejected \\
\hline
\end{tabular}

Table 7 exhibits the results of each component of SMM, taken separately. The result shows that the SMM elements except the distribution have a positive significant effect on perceived quality; this finding is consistent with other researchers' findings (Yoo, et al, 2000; Cobb-walgren, et al.1995) Processes element was the most influential element on perceived quality followed by the promotion, the services nature, people, the price, and physical evidence in order. This may be due to the fact that perceived quality is the consumer's quality perception of the brand when he compares it with other product in the same category so it could be inferred that there is no effect of distribution process on customers' perceived quality.

The researcher found that SMM elements together have a positive significant effect on CBBE dimensions equal 0.553, which is strong relation. This finding is consistent with other researchers' findings (Simon and Sullivan, 1993; Cobb-Walgren, et al., 1995; Akroush and Al-Dmour, 2006; Akroush, et al., 2006). 
Table 8. Coefficient of the Multiple Regression Model/ perceived quality

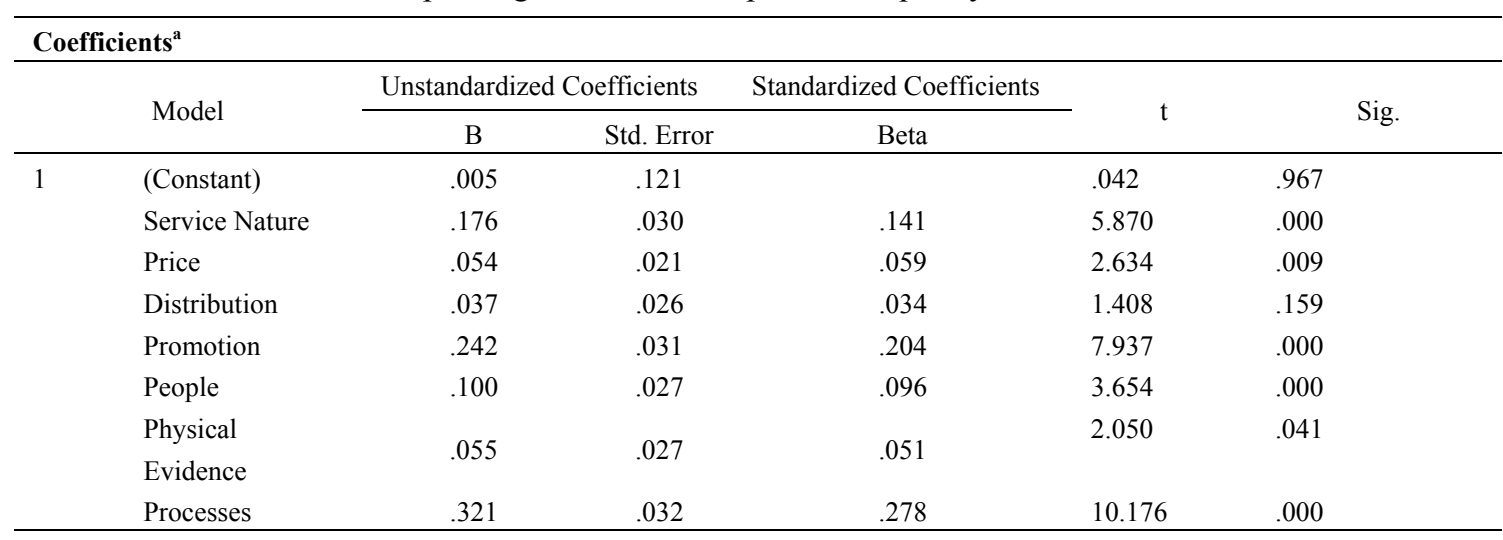

${ }^{\text {a }}$ Dependent Variable: Perceived Quality

\subsubsection{Testing the Fourth Hypothesis}

$\mathrm{H}_{0.4}$ : Services marketing mix elements do not have a significant effect on brand loyalty.

To test this hypothesis the multiple regression test is used, and according to the SPSS analysis, it is found that F calculated $=122.171$ is greater than $F$ tabulated $=2.01$. According to the decision rule, this hypothesis $\mathrm{H}_{0}$ is rejected, meaning; SMM elements have a positive significant effect on brand loyalty. R square value exhibits the capability of the independent variable in predicting the dependent variable; indicating that only $36.6 \%$ of the variation in brand loyalty is explained by SMM. (Table 9).

Table 9. The Result of Multiple Regression Analysis for the effect of SMM elements together on brand loyalty

\begin{tabular}{llllll}
\hline F calculated & F tabulated & F Sig & $\mathrm{R}$ & $\mathrm{R}^{2}$ & Testing Result \\
\hline 122.171 & 2.01 & 000 & .605 & .366 & Rejected \\
\hline
\end{tabular}

Table 10 exhibits the results of each component of SMM . The results show that all the SMM elements have a positive significant effect on brand loyalty. Processes element was the most influential element on brand loyalty followed by the price, the promotion, the services nature, the distribution, people, and physical evidence. This finding is consistent with other researchers' findings (Yoo et al., 2000).

Table 10. Coefficient of the multiple regression model/brand loyalty

\begin{tabular}{|c|c|c|c|c|c|c|}
\hline \multicolumn{7}{|c|}{ Coefficients $^{\mathrm{a}}$} \\
\hline \multirow[t]{2}{*}{ Model } & & \multicolumn{2}{|c|}{ Unstandardized Coefficients } & \multirow{2}{*}{$\begin{array}{c}\text { Standardized Coefficients } \\
\text { Beta } \\
\end{array}$} & \multirow[t]{2}{*}{$\mathrm{t}$} & \multirow[t]{2}{*}{ Sig. } \\
\hline & & $\mathrm{B}$ & Std. Error & & & \\
\hline \multirow[t]{8}{*}{1} & (Constant) & -.223 & .147 & & -1.518 & .129 \\
\hline & Service Nature & .133 & .036 & .092 & 3.658 & .000 \\
\hline & Price & .209 & .025 & .197 & 8.362 & .000 \\
\hline & Distribution & .095 & .032 & .075 & 3.015 & .003 \\
\hline & Promotion & .239 & .037 & .174 & 6.458 & .000 \\
\hline & People & .082 & .033 & .067 & 2.443 & .015 \\
\hline & Physical Evidence & .067 & .033 & .053 & 2.032 & .042 \\
\hline & Processes & .248 & .038 & .185 & 6.486 & .000 \\
\hline
\end{tabular}

\footnotetext{
a Dependent Variable: Brand Loyalty.
}

\section{Conclusions}

A summary of the main research results and findings are presented below:

1) Research findings indicate that there is a statistical significant relationship between SMM and brand awareness and the result showed that the promotion element was the most influential on brand awareness followed by process, physical evidence, the service name and people respectively. 
2) They also indicate that there is a relationship between SMM and brand image and it showed that process element was the most influential one on brand image followed by price, the service itself, the promotion, physical evidence and distribution in order, however, the people element was was found insignificant.

3) Findings also indicate that there is a statistical significant relationship between SMM and brand quality and the process element was the most important one on perceived quality followed by the promotion, serviced, people, the price, and physical evidence respectively, however, the distribution element was found insignificant.

4) The results also showed that there is a statistical significant relationship between SMM and brand locality, and the process was the most influential one on brand locality followed by price, the promotion, the service, the distribution, people and physical evidence.

\subsection{Marketing Implications and Recommendations}

The marketing implications of the study results and recommendations can be summarized as follows:

1) The brand awareness is considered to be an important dimension in CBBE, this dimension could be supported mainly, through the promotion efforts by sending messages to customer's mind about the services; as a result this might increase the service quality, loyalty, and affect positively on brand image.

2) The brand image and perceived quality are two other important dimensions in CBBE, an image created by customers consisting of the knowledge and expectations associated with the service results which showed that both brand image and perceived quality should be supported mainly through the processes.

3) Consumer's commitment to repurchase or otherwise continue using the brand can be demonstrated mainly through the processes that take place within the company.

4) CBBE is a valuable asset for any services sector especially for the marketing managers to assess the results of their efforts by getting the feedback from customers to diagnose any problem that can appeare in the provided service.

5) In addition, $\mathrm{CBBE}$ gives the managers structured approach for designing and creating the branding strategy, because it is a model when you know the appropriate components then it becomes a routinely way that could be then modified according to any situational issue. Based on that the managers will be able to solve the problems that could be aroused from the limited resources they have, because they gain sufficient knowledge about how to utilize and employ resources in an efficient way.

6) Many problems aroused from the characteristics of the service; inseparability, heterogeneity, and perishability. However, the most crucial for marketing managers is intangibility. Of course focusing on Tangible cues, using personal sources more than nonpersonal sources, also emphasizing on the importance of word-of-mouth communications and finally build strong image could affect positively on CBBE.

7) These four problems should be given enough attention because if these problems are not carefully managed, they will usually have a negative effect on the perceived quality and the image of the company and this will reduce the customer's retention and loyalty.

8) Finding and winning customers these days is not an easy job, but keeping them is more important, because when the firm is capable of keeping its customer then they necessarily become loyal for it. Moreover, when it reaches this point this means that it has a good SMM combination, as a result the customers will talk about its services positively. And this would be reflected on the brand image.

9) People could have a magnificence role on CBBE. The quality of a service can vary from service providers; this lack of homogeneity in services can be solved by the well-trained employees, as services are delivered through contact between customers and employees, and attention to the behavior and attitudes of service providers can therefore greatly influence customers' views and loyalties.

\subsection{Future Research Areas}

The researchers suggest the following future studies:

1) Apply this study on other services sectors in order to generalize and validate the results of this study.

2) The distinctions between CBBE dimensions and marketing could be tested by performing a comparative study of the industrial sector and service sector.

3) Apply this study on other Arab countries in order to gain more validation and generalized findings.

4) Measure the brand equity from the company's point of view or through financial measurements. 
5) Investigate $\mathrm{CBBE}$ more by using other brand equity dimensions.

\section{References}

Aaker, D. (1991). Managing Brand Equity: Capitalizing on the value of a brand name. New York, NY: The Free Press.

Aaker, D. (1996). Measuring brand equity across products and markets. California Management Review, 38(3), 102-20. http://dx.doi.org/10.2307/41165845

Aaker, D., \& Álvarez Del, B. (1995). Estatura de la marca: medir el valor por productos y mercados -Stature of the brand: Measuring the value by products and markets. Harvard-Deusto Business Review, 69(3), 74-87.

Agarwal, M. K., \& Rao, V. R. (1996). An Empirical Comparison of Consumer-Based Measures of Brand Equity. Marketing Letters, 7(3), 237-247. http://dx.doi.org/10.1007/BF00435740

Akroush, M., \& Al-Dmour, H. (2006). The Relationship between Brand-Building Factors and Branding Benefits in Commercial Banks Operating in Jordan: An Empirical Investigation of managers' perspectives. Jordan Journal of Business Administration, 2(3), 464-486.

Anderson, W., \& Sullivan, M. (1993). The Antecedents and Consequences of Customer Satisfaction. Marketing Science, 12(3), 125-143. http://dx.doi.org/10.1287/mksc.12.2.125

Bitner, M. (1990). Evaluating Service Encounters: the Effects of Physical Surroundings and Employee Responses. Journal of Marketing, 54(2), 69-82. http://dx.doi.org/10.2307/1251871

Bitner, M. (1992). Service scapes: The effect of Physical Surroundings on Customers and Employees. Journal of Marketing, 56(2), 57-71. http://dx.doi.org/10.2307/1252042

Booms, B., \& Bitner, M. (1981). Marketing Strategies and Organisation Structures for Service Firms. In Marketing of Services Special Educators' Conference Proceedings, Chicago, American. Marketing Association, 46-51.

Borden, N. (1964). The Concept of the marketing mix. Journal of Advertising Research, 2-7.

Business Week. (2003). The 100 top brands. Business Week, 8(4), 72-8.

Cobb-Walgren, C., \& Ruble, C. (1995). Brand equity, brand preference, and purchase intent. Journal of Advertising, 24(3), 25-41.

Department of Statistics. (2009). Statistical Yearbook. Amman, Jordan.

Faircloth, J., Capella, L., \& Alford, B. (2001). The effect of brand attitude and brand image on brand equity. Journal of Marketing Theory and Practice, 9(3), 61-75.

Farquhar, P. (1989). Managing brand equity. Journal of Marketing Research, 24-34.

Fornell, C., Johnson, M., Anderson, E., Cha, J., \& Everitt, B. (1996). The American customer satisfaction index: Nature, purpose, and findings. Journal of Marketing, 60, 7-18. http://dx.doi.org/10.2307/1251898

Gronroos, C. (1978). A Service-Oriented approach to Marketing of Services. European Journal of Marketing, 12(8), 588-601. http://dx.doi.org/10.1108/EUM0000000004985

Gronroos, C. (1994). From Marketing Mix to Relationship Marketing: Towards a Paradigm Shift in Marketing. Management Decision, 32(2), 4-20. http://dx.doi.org/10.1108/00251749410054774

Grönroos, C. (2001). The perceived service quality concept-a mistake? Managing Service Quality, 11(3), 150-152. http://dx.doi.org/10.1108/09604520110393386

Hallowell, R. (1996). The relationships of customer satisfaction, customer loyalty, and profitability: an empirical study. International Journal of Service Industry Management, 7(1), 27-42. http://dx.doi.org/10.1108/09564239610129931

Kayaman, R., \& Arasli, H. (2007). Customer based brand equity:evidence from the hotel industry. Managing Service Quality, 17(1), 92-109. http://dx.doi.org/10.1108/09604520710720692

Keller, K., \& Lehmann, D. (2003). How Do Brands Create Value. Marketing Management, 12(3), 26-31.

Keller, K. (1993). Strategic Brand Management (3rd ed.). Upper saddle river, New Jersey: Pearson education, Inc.

Keller, K. (2001). Building customer-based brand equity: A blueprint for creating strong brands. Marketing Management, 10, 15-19.

Keller, K. (2008). Conceptualizing, measuring, and managing customer-based brand equity. Journal of Marketing, 
57, 1-22. http://dx.doi.org/10.2307/1252054

Keller, K. (2008). Strategic Brand Management: Building, Measuring and Managing Brand Equity (3rd ed.). Upper Saddle River, Pearson, NJ.

Kent, R. (1986). Faith in the four Ps: an alternative. Journal of Marketing Management, 2(2), 145-154. http://dx.doi.org/10.1080/0267257X.1986.9964007

Kim, M., Park, M., \& Jeong, D. (2004). The effects of customer satisfaction and switching barrier on customer loyalty in Korean mobile telecommunication services. Telecommunications Policy, 28(2), 145-159. http://dx.doi.org/10.1016/j.telpol.2003.12.003

Kotler, P., Wong, V., Saunders, J., \& Armstrong, G. (2005). Principles of marketing, European edition (4th ed.). Prentice Hall International Inc.

Langeard, E., Bateson, J., Lovelock, C., \& Eiglier, P. (1981). Service Marketing: New Insights from Consumer and Managers. Cambridge, MA: Marketing Science Institute.

Lassar, W., Mittal, B., \& Sharma, A. (1995). Measuring Customer-Based Brand Equity. Journal of Consumer Marketing, 12(4), 11-19. http://dx.doi.org/10.1108/07363769510095270

Lovelock, C., \& Wirtz, J. (2007). Services Marketing: People, Technology, Strategy (6th ed.). Pearson education limited.

Low, G., \& Lamb, Jr. C., (2000). The measurement and dimensionality of brand associations. Journal of Product and Brand Management, 9(6), 350-368. http://dx.doi.org/10.1108/10610420010356966

Oliver, L. (1999). Whence consumer loyalty? Journal of Marketing, 63(Special Issue), 33-44. http://dx.doi.org/10.2307/1252099

Onkvisit, S., \& Shaw, J. (1989). Service Marketing Image, Branding, and Competition. Business Horizon, 32(1), 13-20. http://dx.doi.org/10.1016/0007-6813(89)90018-9

Pitt, L., \& McCarthy, I. P. (2008). Connecting Product Innovation Management and Marketing. Journal of Commercial Biotechnology, 14(3), 197-200. http://dx.doi.org/10.1057/jcb.2008.19

Prasad, K., \& Dev, C. (2000). Managing hotel brand equity: A customer-centric framework for assessing performance. Cornell Hotel and Restaurant Administration Quarterly, 41(3), 22-31. http://dx.doi.org/10.1177/001088040004100314

Rajh, E., \& Došen, D. (2009). The Effects Of Marketing Mix Elements On Service Brand Equity. Economic Research, 22(4), 69-83.

Rathmell, J. (1966). What is Meant by Services? Journal of Marketing, 30(October), 32-36. http://dx.doi.org/10.2307/1249496

Rathmell, J. (1974). Marketing in the Services Sector. Cambridge, MA: Winthrop.

Shostack, G. (1977). Breaking free from product marketing. Journal of Marketing, 41(April), 73-80. http://dx.doi.org/10.2307/1250637

Simon, C., \& Sullivan, M. (1993). The measurement and determinants of brand equity: a financial approach. Marketing Science, 12(1), 28-53. http://dx.doi.org/10.1287/mksc.12.1.28

Yoo, B., Donthu, N., \& Lee, S. (2000). An examination of selected marketing mix elements and brand equity. Journal of the Academy Of Marketing Science, 28(2), 195-211. http://dx.doi.org/10.1177/0092070300282002

Zeithaml, V. (1988), Consumer perceptions of price, quality, and value: a means-end model and synthesis of evidence. Journal of Marketing, 52(July), 2-22. http://dx.doi.org/10.2307/1251446

Zeithaml, V., \& Bitner, M. (2000). Services Marketing: Integrating Customer Focus Across the Firm (2nd ed.). Irwin McGraw-Hill.

Zeithaml, V., Parasuraman, A., \& Berry, L. (1985). Problems and Strategies in Services Marketing. Journal of Marketing, 49(2), 33. http://dx.doi.org/10.2307/1251563 